\title{
Formation and speciation of disinfection byproducts during chlor(am)ination of aquarium seawater
}

\author{
Haiting Zhang ${ }^{1}$, Huiyu Dong ${ }^{1}$, Craig Adams ${ }^{2}$, Zhimin Qiang ${ }^{1, *}$, Gang Luan ${ }^{3}$, Lei Wang ${ }^{3}$ \\ 1. Key Laboratory of Drinking Water Science and Technology, Research Center for Eco-Environmental Sciences, Chinese Academy of Sciences, \\ Beijing 100085, China. E-mail: zhanghaiting7@gmail.com \\ 2. Department of Civil and Environmental Engineering, Utah State University, Logan, UT 84322, US \\ 3. Water Quality Analysis and Control Center, Department of Life Support Equipments for Aquatic Animals, Beijing Aquarium, Beijing 100081, \\ China
}

\section{A R T I C L E I N F O}

Article history:

Received 16 July 2014

Revised 23 November 2014

Accepted 1 December 2014

Available online 29 April 2015

\section{Keywords:}

Disinfection byproducts

Chlorination

Chloramination

Pre-ozonation

Bromine substitution factor

Aquarium seawater

\begin{abstract}
A B S T R A C T
The chemistry associated with the disinfection of aquarium seawater is more complicated than that of freshwater, therefore limited information is available on the formation and speciation of disinfection byproducts (DBPs) in marine aquaria. In this study, the effects of organic precursors, bromide $\left(\mathrm{Br}^{-}\right)$and pre-ozonation on the formation and speciation of several typical classes of DBPs, including trihalomethanes (THM4), haloacetic acids (HAAs), iodinated trihalomethanes (I-THMs), and haloacetamides (HAcAms), were investigated during the chlorination/chloramination of aquarium seawater. Results indicate that with an increase in dissolved organic carbon concentration from 4.5 to $9.4 \mathrm{mg} / \mathrm{L}$, the concentrations of THM4 and HAAs increased by 3.2-7.8 times under chlorination and by 1.1-2.3 times under chloramination. An increase in $\mathrm{Br}^{-}$concentration from 3 to $68 \mathrm{mg} / \mathrm{L}$ generally enhanced the formation of THM4, I-THMs and HAcAms and increased the bromine substitution factors of all studied DBPs as well, whereas it impacted insignificantly on the yield of HAAs. Pre-ozonation with $1 \mathrm{mg} / \mathrm{L} \mathrm{O}_{3}$ dose substantially reduced the formation of all studied DBPs in the subsequent chlorination and I-THMs in the subsequent chloramination. Because chloramination produces much lower amounts of DBPs than chlorination, it tends to be more suitable for disinfection of aquarium seawater.
\end{abstract}

C 2015 The Research Center for Eco-Environmental Sciences, Chinese Academy of Sciences. Published by Elsevier B.V.

\section{Introduction}

There are at least 240 large marine aquaria and life centers throughout the world (MarineBio, 2012). Chemical disinfectants are widely used in such facilities to inactivate pathogens while protecting marine animal health (Wang et al., 2014), including ozone $\left(\mathrm{O}_{3}\right)$, chlorine dioxide $\left(\mathrm{ClO}_{2}\right)$, chlorine $\left(\mathrm{Cl}_{2}\right)$, and chloramine $\left(\mathrm{NH}_{2} \mathrm{Cl}\right)$. However, these disinfectants can react with water constituents, such as dissolved organic matter (DOM), ammonia, bromide $\left(\mathrm{Br}^{-}\right)$, and iodide $\left(\mathrm{I}^{-}\right)$, to form a variety of hazardous disinfection byproducts (DBPs), especially in a recirculating mariculture system (RMS) (Shi et al., 2013; Qiang et al., 2015). RMS enables the treatment of polluted water within a closed loop, offers improved control of effluent discharge, and allows complete environmental control, and thus has been preferentially employed to deal with the ecological problems associated with seawater in marine aquaculture (Sharrer et al., 2007).

$\mathrm{O}_{3}$, which is primarily used to improve the physicochemical aspects of water quality rather than to provide disinfection (Tango and Gagnon, 2003), has multiple functions, such as

${ }^{*}$ Corresponding author. E-mail: qiangz@rcees.ac.cn (Zhimin Qiang). 
decomposing DOM and controlling algae, color, odor, and taste (Gonçalves and Gagnon, 2011). Another persistent disinfectant (e.g., $\mathrm{ClO}_{2}, \mathrm{Cl}_{2}$, or $\mathrm{NH}_{2} \mathrm{Cl}$ ) is necessary to maintain continuous disinfection capability because $\mathrm{O}_{3}$ cannot provide a persistent residue in water distribution systems. $\mathrm{ClO}_{2}$ has been recently adopted as a disinfectant in some RMSs; however, its use is typically accompanied by the continuous accumulation of $\mathrm{ClO}_{3}^{-}$. For example, the $\mathrm{ClO}_{3}^{-}$concentration in Beijing Aquarium from our previous research could reach as high as $55 \mathrm{mg} / \mathrm{L}$ (Qiang et al., 2015), which exceeds the United States Environmental Protection Agency (USEPA)-regulated maximum contaminant level (MCL) for drinking water by a factor of nearly $55 . \mathrm{Cl}_{2}$ is the most frequently used disinfecting agent in drinking water treatment because of its low cost and high disinfection capacity, whereas undesirable DBPs with potentially harmful health effects, especially trihalomethanes (THMs) and haloacetic acids (HAAs), can be produced in the chlorination process (Cowman and Singer, 1996). Many utilities have been switching from $\mathrm{Cl}_{2}$ to $\mathrm{NH}_{2} \mathrm{Cl}$ disinfection to meet the more stringent regulations on THMs and HAAs. However, $\mathrm{NH}_{2} \mathrm{Cl}$ may promote the formation of iodinated trihalomethanes (I-THMs) and nitrogenous DBPs (N-DBPs) (e.g., haloacetamides (HAcAms)). Richardson et al. (2007) suggested that I-THMs could be more toxic than their brominated and chlorinated analogues. A toxicologic study also indicated that the HAcAms are 142 times more cytotoxic than HAAs and 12 times more genotoxic than HAAs (Plewa et al., 2008).

$\mathrm{Br}^{-}$concentration plays an important role in the formation and speciation of DBPs because it can be readily oxidized to free bromine ( $\mathrm{FB}, \mathrm{HOBr} / \mathrm{OBr}^{-}$) in the disinfection process (Qiang et al., 2012). FB can further react with other inorganic or organic compounds to produce harmful DBPs (e.g., THMs, HAAs, and I-THMs) (Jones et al., 2012), such that the formation of organic DBPs shifts to more brominated species that are dozens to hundreds of times more cytotoxic and genotoxic than their chlorinated analogues (Richardson et al., 2007). Bromine substitution factor (BSF) has been used to evaluate the substitution extent of DBPs by bromine, which is defined as the molar ratio of bromine incorporated into a given class of DBPs to the sum of chlorine and bromine (Hua et al., 2006).

Pre-ozonation has been commonly applied in the foam fractionation process of aquarium seawater treatment systems to enhance the removal of suspended solids and DOM (Suzuki and Maruyama, 2002). The effect of pre-ozonation on the formation of DBPs depends on water quality parameters (Hua and Reckhow, 2013).

Considerable efforts have been exerted to understand the formation mechanisms of THMs, HAAs, I-THMs, and HAcAms in drinking water. However, the chemistry associated with the disinfection of aquarium seawater is more complex than that of freshwater because of the higher concentrations of inorganic ions (e.g., $\mathrm{Cl}^{-}, \mathrm{Br}^{-}, \mathrm{I}^{-}$) and organic materials therein (Shi et al., 2013). Therefore, limited information is available on the formation and speciation of disinfection byproducts (DBPs) in marine aquaria. In this study, THM4, dihaloacetic acids (DHAAs), trihaloacetic acids (THAAs), I-THMs, dihaloacetamides (DHAcAms), and trihaloacetamides (THAcAms) were selected as representative DBPs. The effects of $\mathrm{DOM}, \mathrm{Br}^{-}$concentration, and pre-ozonation on the formation and associated BSFs of selected DBPs in the chlorination/chloramination of aquarium seawater were evaluated systematically. This study could help marine aquaria to optimize and update their seawater treatment systems for water quality improvement and animal health protection.

\section{Materials and methods}

\subsection{Chemicals and standards}

The DBP standards THM4 (chloroform, TCM; bromodichloromethane, BDCM; dibromochloromethane, DBCM; bromoform, TBM), DHAAs (dichloroacetic acid, DCAA; bromochloroacetic acid, BCAA; dibromoacetic acid, DBAA), and THAAs (trichloroacetic acid, TCAA; bromodichloroacetic acid, DCBAA; dibromochloroacetic acid, DBCAA; tribromoacetic acid, TBAA) were purchased from Accustandard (New Haven, CT, US). I-THMs (dichloroiodomethane, DCIM; bromochloroiodomethane, BCIM; dibromoiodomethane, DBIM; chlorodiiodomethane, CDIM; bromodiiodomethane, BDIM; triiodomethane, TIM), DHAcAms (dichloroacetamide, DCAcAm; bromochloroacetamide, BCAcAm; dibromoacetamide, DBAcAm), and THAcAms (trichloroacetamide, TCACAm; bromodichloroacetamide, DCBAcAm; dibromochloroacetamide, DBCAcAm; tribromoacetamide, TBAcAm) were purchased from CanSyn (Toronto, Ontario, Canada). All of these chemicals (of analytical grade at least) were of the highest purity available. All aqueous solutions were prepared with ultrapure water produced by a Milli-Q system (Advantage A10, Millipore, Billerica, MA, US). HPLC-grade hexane and methyl-tert-butyl ether were purchased from Fisher Scientific (Houston, TX, US). Diethyl-p-phenylenediamine test kits were purchased from Hach Company (Loveland, CO, US).

\subsection{Characteristics of water samples}

Beijing Aquarium is a typical RMS with a total seawater volume of $18,000 \mathrm{~m}^{3}$. Fresh artificial seawater is prepared with all major ions added externally, including $\mathrm{Na}^{+}(9.50 \mathrm{~g} / \mathrm{L}), \mathrm{Mg}^{2+}(1.15 \mathrm{~g} / \mathrm{L})$, $\mathrm{K}^{+}(0.35 \mathrm{~g} / \mathrm{L}), \mathrm{Ca}^{2+}(0.37 \mathrm{~g} / \mathrm{L}), \mathrm{Cl}^{-}(17.10 \mathrm{~g} / \mathrm{L}), \mathrm{SO}_{4}^{2-}(2.25 \mathrm{~g} / \mathrm{L})$, and $\mathrm{HCO}_{3}^{-}(0.14 \mathrm{~g} / \mathrm{L})$, to simulate the ion ratios of natural seawater (3.0\%-3.5\% salinity). The prepared artificial seawater is treated by $\mathrm{O}_{3}$ and then supplied to non-mammal (e.g., big fish, jellyfish, coral) and mammal (e.g., dolphin, sea lion, white whale) tanks in sequence, to compensate the volume loss during treatment and recycling. Raw seawater samples were collected from the big fish tank (BFT) and sea lion tank (SLT). Both tanks adopt decentralized treatment, which includes sand filtration, foam fractionation, and disinfection. For the $\mathrm{BFT}, \mathrm{O}_{3}$ is first injected online into the foam fractionation facility, from which suspended solids are removed by air floatation, and a certain portion of DOM is decomposed by $\mathrm{O}_{3}$ oxidation. The penetrating solid particles are further removed by sand filtration. Thereafter, a side stream of the sand-filtered seawater comes in contact with $\mathrm{O}_{3}$ for approximately $5 \mathrm{~min}$ (i.e., bypass treatment) and then merges with the main stream to return to the BFT. The used seawater from the BFT further flows into the mammal tanks (i.e., SLT), in which $\mathrm{O}_{3}$ is used as the primary disinfectant, followed by $\mathrm{ClO}_{2}$ as the secondary disinfectant, to provide a persistent residue. 
Table 1 - Major characteristics of tested seawater samples.

\begin{tabular}{|c|c|c|c|c|c|c|}
\hline Samples & DOC (mg/L) & $\mathrm{UV}_{254}(1 / \mathrm{cm})$ & SUVA $(\mathrm{L} /(\mathrm{mg} \cdot \mathrm{m}))$ & TN (mg/L) & $\mathrm{NO}_{3}^{-}-\mathrm{N}(\mathrm{mg} / \mathrm{L})$ & $\mathrm{pH}$ \\
\hline Big fish tank (BFT) & 4.5 & 0.042 & 0.93 & 65 & 61 & 7.86 \\
\hline Sea lion tank (SLT) & 9.4 & 0.085 & 0.90 & 325 & 318 & 7.98 \\
\hline
\end{tabular}

The dissolved organic carbon (DOC) concentration in the mammal SLT was $9.4 \mathrm{mg} / \mathrm{L}$ (Table 1), about twice that in the non-mammal BFT (i.e., $4.5 \mathrm{mg} / \mathrm{L}$ ). The selection of these two tanks enables us to evaluate the effect of DOC concentration on DBP formation. The specific UV absorbance (SUVA) values in both tanks were lower than $2 \mathrm{~L} /(\mathrm{mg} \cdot \mathrm{m})$, indicating a high hydrophilicity for the DOM (Weishaar et al., 2003) under the oxidizing environment in the recirculating seawater system. Total nitrogen (TN) was measured at high concentrations in the two tanks (i.e., BFT, $65 \mathrm{mg} / \mathrm{L}$; SLT, $325 \mathrm{mg} / \mathrm{L}$ ), which was primarily composed of $\mathrm{NO}_{3}^{-}$.

\subsection{Experimental procedures}

Monochloramine was freshly prepared prior to each test following a previous study (Qiang and Adams, 2004). DBP formation tests primarily followed the procedures reported by Liang and Singer (2003). Specifically, seawater samples from the above two tanks were chlorinated $(20.0 \mathrm{mg} / \mathrm{L}$, or $0.28 \mathrm{mmol} / \mathrm{L}$ ) or chloraminated $(14.5 \mathrm{mg} / \mathrm{L}$, or $0.28 \mathrm{mmol} / \mathrm{L})$, stored headspace-free in the dark for $24 \mathrm{hr}$ at room temperature $\left(20^{\circ} \mathrm{C} \pm 1^{\circ} \mathrm{C}\right)$, quenched with $\mathrm{Na}_{2} \mathrm{~S}_{2} \mathrm{O}_{3}$, and extracted for DBP analyses.

The background concentration of $\mathrm{Br}^{-}$in the artificial seawater of Beijing Aquarium is about $3 \mathrm{mg} / \mathrm{L}$. The effect of $\mathrm{Br}^{-}$concentration on the formation of DBPs was evaluated with seawater from the SLT by spiking with $\mathrm{Br}^{-}$concentrations of 0,30 , and $65 \mathrm{mg} / \mathrm{L}$. The effect of pre-ozonation on the formation of DBPs was evaluated at various $\mathrm{O}_{3}$ doses $(0,1,3$, and $5 \mathrm{mg} / \mathrm{L})$ with a contact time of $15 \mathrm{~min}$. After ozonation, chlorination or chloramination tests were conducted following the procedures described above. The background concentration of total inorganic iodine in natural seawater is usually about $0.45 \mu \mathrm{mol} / \mathrm{L}$ (Moren et al., 2008); however, from the reported $\mathrm{IO}_{3}^{-}$concentrations (e.g., $184 \mu \mathrm{g} / \mathrm{L}$ ) detected in some marine aquaria (Shi et al., 2013), higher $\mathrm{I}^{-}$concentrations could be inferred in animal tanks. Therefore, when investigating the impact of $\mathrm{Br}^{-}$concentration and pre-ozonation on the formation of I-THMs, a certain amount of $\mathrm{I}^{-}$ions was spiked into the seawater to reach an initial concentration of $500 \mu \mathrm{g} / \mathrm{L}$.

\subsection{Analytic methods}

The DOC concentration was analyzed with a Total Organic Carbon Analyzer (Phoenix 8000, Tekmar-Dohrmann Co., Manson, $\mathrm{OH}, \mathrm{US})$ after filtering the samples through $0.45 \mu \mathrm{m}$ glass fiber filters. UV absorbance at $254 \mathrm{~nm}\left(\mathrm{UV}_{254}\right)$ was measured using a Hach DR5000 spectrophotometer (Loveland, CO, US), and SUVA was calculated by dividing the $\mathrm{UV}_{254}$ by the DOC concentration. TN was detected according to method GB/T 12763.4-2007 from the Specification for Oceanographic Survey of China, which is specific for chemical analyses in seawater. For $\mathrm{NO}_{3}^{-}$measurements, each sample was filtered through an OnGuard II Ag cartridge and an OnGuard II H cartridge in sequence (i.e., to remove the predominant $\mathrm{Cl}^{-}$ions and the released $\mathrm{Ag}^{+}$ions, respectively), and then analyzed by an ICS-2000 ion chromatograph (Dionex, Sunnyvale, CA, US). THM4 and HAAs were analyzed by an Agilent 7890A gas chromatograph (GC, Agilent Technologies, Wilmington, DE, US) coupled with an electron capture detector (ECD) on the basis of USEPA methods 551.1 and 552.2, respectively. I-THMs and HAcAms were also analyzed by GC/ECD after liquid-liquid extraction (Weinberg et al., 2002; Hua et al., 2006).

\section{Results and discussion}

\subsection{Effect of DOC concentration on DBP formation}

The DOC concentration of seawater can influence significantly the formation of THM4, DHAAs, and THAAs during disinfection since organic matter has been recognized as the precursor of DBPs (Wang et al., 2014). Fig. 1 confirms that the DBP yields under chloramination $(<25 \mu \mathrm{g} / \mathrm{L})$ were much less than those under chlorination (40-360 $\mu \mathrm{g} / \mathrm{L})$. A significant reduction in HAA yields (90\%-95\%) was also reported when chlorination was switched to chloramination (Cowman and Singer, 1996). As the DOC concentration increased from 4.5 to $9.4 \mathrm{mg} / \mathrm{L}$, the formation of THM4, DHAAs, and THAAs was enhanced by 3.2-7.8 times upon chlorination and by only 1.1-2.3 times upon chloramination. For example, the yield of DHAAs increased from 42.6 to $334.4 \mu \mathrm{g} / \mathrm{L}$ under chlorination while only increasing from 4.1 to $4.4 \mu \mathrm{g} / \mathrm{L}$ under chloramination.

THM4 exhibited a notably lower concentration than HAAs (i.e., the sum of DHAAs and THAAs) under both chlorination and chloramination. The relative ratio of HAAs to THM4 is believed

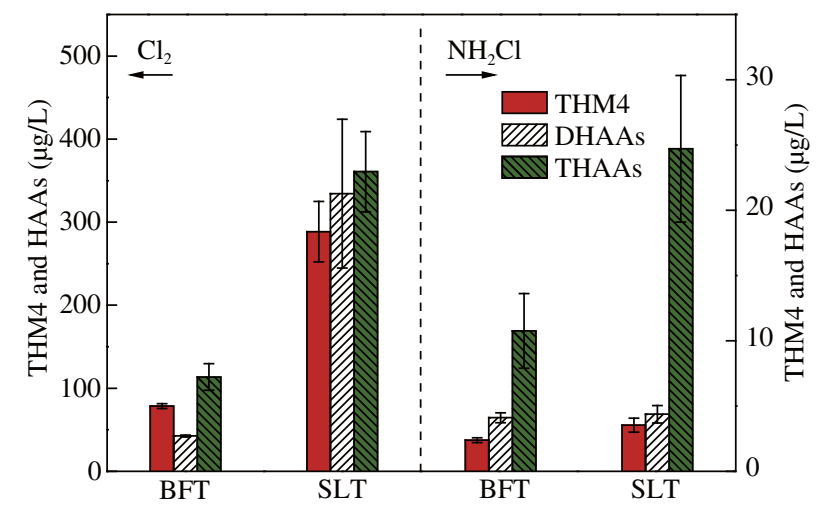

Fig. 1 - Effect of DOC concentration on the formation of THM4, DHAAs, and THAAs under chlorination and chloramination. DOC concentrations were 4.5 and $9.4 \mathrm{mg} / \mathrm{L}$ for BFT and SLT, respectively; $\mathrm{pH}=7.8-8.2$; error bars represent the standard deviations of triplicate experiments. DOC: dissolved organic carbon; THM4: trihalomethanes; DHAAs: dihaloacetic acids; THAAs: trihaloacetic acids; BFT: big fish tank; SLT: sea lion tank. 
to be influenced by the hydrophobic/hydrophilic distribution of DOM in the water being disinfected. Liang and Singer (2003) found that the hydrophilic fraction was a more significant precursor for THM4 than for HAAs. In this study, under a constant oxidizing pressure in the test tanks disinfected by $\mathrm{O}_{3}$ (i.e., $\mathrm{BFT}$ ) or $\mathrm{O}_{3} / \mathrm{ClO}_{2}$ (i.e., SLT), the hydrophilic fraction was reasonably expected to be the dominant species, which thus led to a higher yield of HAAs than THM4. The result clearly manifests a higher demand on $\mathrm{DOC}$ reduction for chlorination than for chloramination. If $\mathrm{ClO}_{2}$ is to be replaced by $\mathrm{Cl}_{2}$ as the residual disinfectant, a significant removal of DOC is necessary prior to chlorination.

\subsection{Effect of $\mathrm{Br}^{-}$concentration on DBP formation}

\subsubsection{Formation of THM4 and HAAs}

Fig. 2 shows that the spiked $\mathrm{Br}^{-}$significantly promoted the formation of THM4 under both chlorination and chloramination.
With an increase in $\mathrm{Br}^{-}$concentration from 3 to 33 and $68 \mathrm{mg} / \mathrm{L}$, the THM4 concentration quickly increased from 288.5 to 435.9 and $534.8 \mu \mathrm{g} / \mathrm{L}$ upon chlorination; the THM4 concentration also showed a quick increase upon chloramination, but was always less than $10 \mu \mathrm{g} / \mathrm{L}$. By contrast, the formation of DHAAs maintained quite stable, while the formation of THAAs decreased with increasing $\mathrm{Br}^{-}$concentration in both disinfection scenarios. Cowman and Singer (1996) found that the formation of DHAAs and THAAs was fairly constant over the $\mathrm{Br}^{-}$range of $0-25 \mu \mathrm{mol}$ during the chlorination of humic substances extracted from surface and ground waters. However, Hua et al. (2006) reported opposite conclusions for the disinfection of source waters collected from drinking water treatment plant intakes. The distinction between the two observations could probably lie in the differing nature of organic precursors and the different reaction times adopted. The present and Cowman and Singer's studies had a shorter reaction time (24 hr) than Hua's (48 hr),

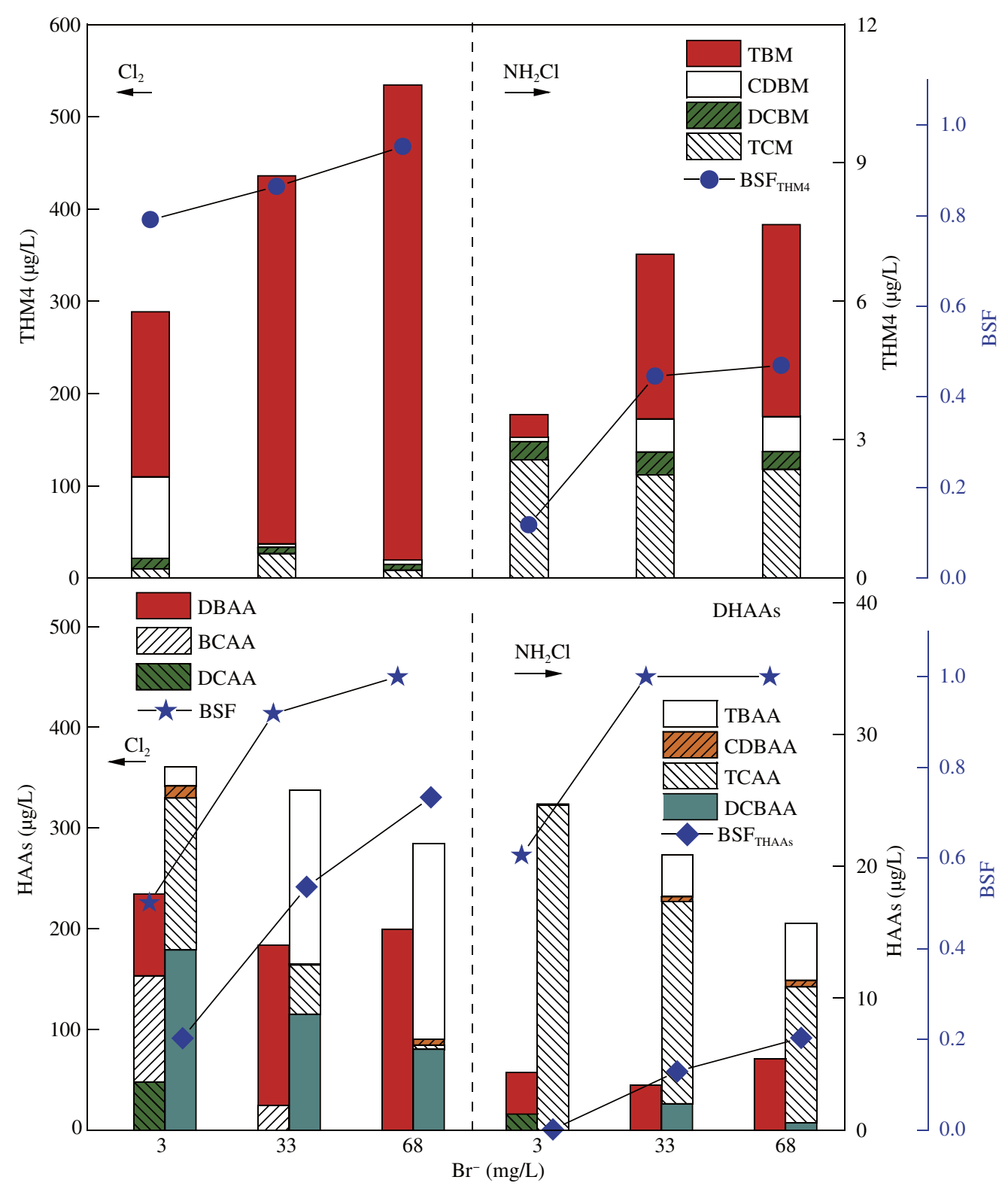

Fig. 2 - Effect of $\mathrm{Br}^{-}$concentration on the formation and associated bromine substitution factor (BSF) values of THM4 and HAAs (SLT seawater; $\mathrm{pH}=8.0-8.2)$. The relative percent differences of all measurement data were below $15 \%(n=2)$. 
whereas the increase in HAA concentration with $\mathrm{Br}^{-}$could become more pronounced at longer reaction times (Wu and Chadik, 1998).

The species of THM4, DHAAs and THAAs shifted to more brominated ones (i.e., TBM, CDBM, DBAA, and TBAA) with increasing $\mathrm{Br}^{-}$concentration upon chlorination and chloramination, and their BSF values showed an increase correspondingly. THAAs had the lowest BSFs under both chlorination and chloramination, which agrees with the result reported from the Information Collection Rule Data (Obolensky and Singer, 2005), in which the BSFs of DHAAs and THM4 were comparable, whereas bromine substitution in THAAs was $10 \%$ lower than that in THM4. The BSFs under chlorination were notably higher than (for THM4 and THAAs) or comparable to (for DHAAs) those under chloramination. It is known that free chlorine (FC, $\mathrm{HOCl} / \mathrm{OCl}^{-}$) can readily oxidize $\mathrm{Br}^{-}$ to $\mathrm{FB}$, and then $\mathrm{FB}$ further reacts with $\mathrm{DOM}$ to produce more brominated DBPs.

\subsubsection{Formation of I-THMs and HAcAms}

The formation of I-THMs (spiked I- concentration $=500 \mu \mathrm{g} / \mathrm{L}$ ) under chlorination increased significantly from 32.3 to 57.0, and $72.1 \mu \mathrm{g} / \mathrm{L}$ with the increase in $\mathrm{Br}^{-}$concentration (Fig. 3). DCIM was the dominant species at low $\mathrm{Br}^{-}$concentration (i.e., $3 \mathrm{mg} / \mathrm{L}$ ) under chlorination, while the concentration of BCIM caught up at high $\mathrm{Br}^{-}$concentrations (i.e., 33 and $68 \mathrm{mg} / \mathrm{L}$ ). This indicates that more bromine was involved in the formed I-THMs with the increase in $\mathrm{Br}^{-}$concentration. By contrast, TIM was always

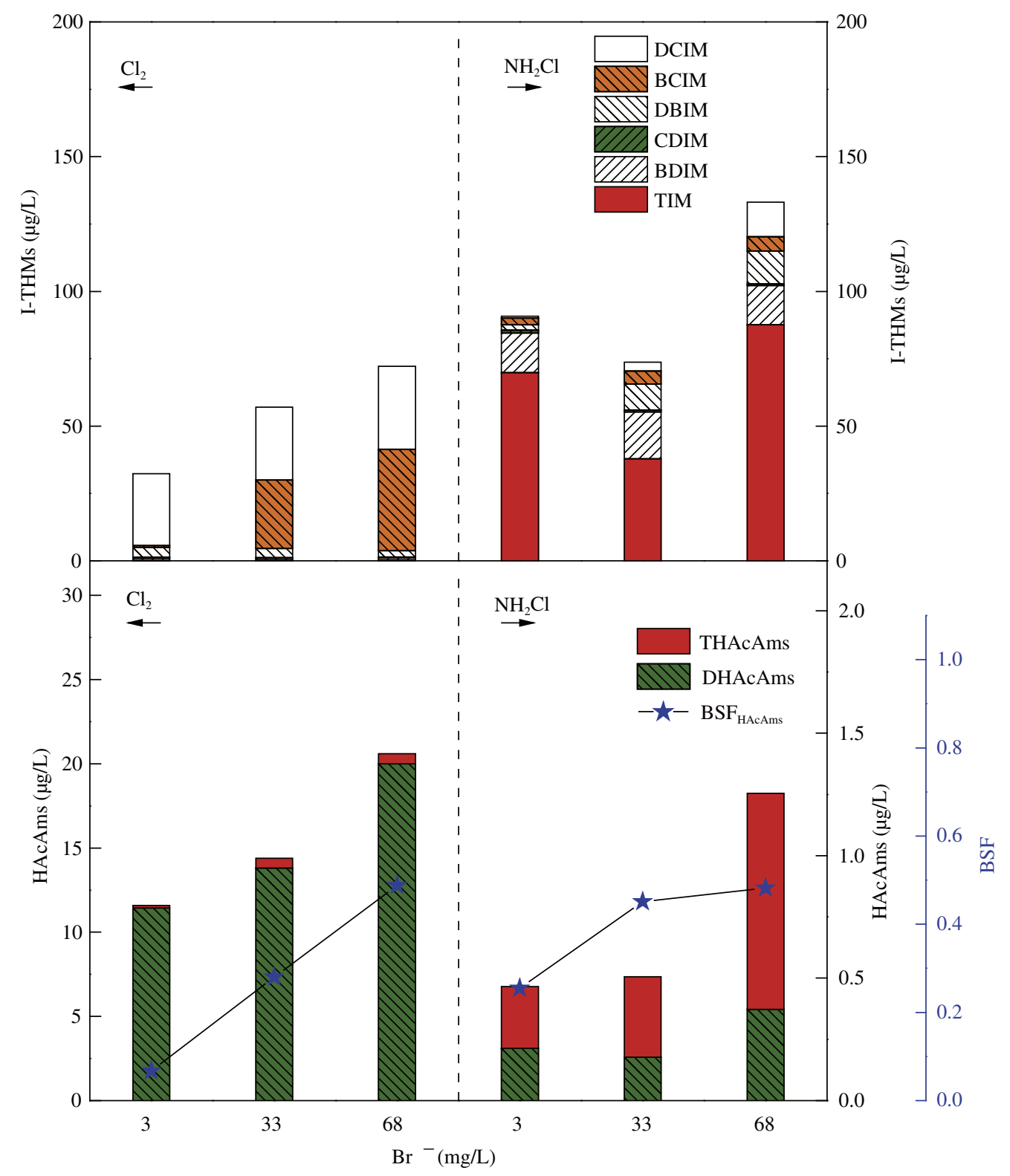

Fig. 3 - Effect of $\mathrm{Br}^{-}$concentrations on the formation of $\mathrm{I}-\mathrm{THMs}$ and HAcAms (SLT seawater; $\mathrm{pH}=8.0-8.2$; spiked $\mathrm{I}^{-}$concentration = $500 \mu \mathrm{g} / \mathrm{L})$. The relative percent differences of all measurement data were below $12 \%(n=2)$. I-THMs: iodinated trihalomethanes; HAcAms: haloacetamides. 
the dominant species of I-THMs upon chloramination, and the spiked $\mathrm{Br}^{-}$notably promoted the formation of DBIM. It is particularly noted that chlorination produced more THM4 and HAAs than I-THMs, while chloramination exhibited an opposite trend (Figs. 2 and 3). Furthermore, chloramination even produced more I-THMs than chlorination under identical experimental conditions. This is because hypoiodous acid (HOI) was formed upon the chloramination of $\mathrm{I}^{-}$-containing waters, which could further react with DOM to yield iodinated DBPs (Allard et al., 2013). On the other hand, FC could easily oxidize HOI to iodate, which is non-toxic and is therefore a preferred sink of iodine (Bichsel and von Gunten, 1999). It should be pointed out that no $\mathrm{I}^{-}$ions were externally added when preparing the artificial seawater in Beijing Aquarium. Our control experiment, without the spiked $\mathrm{I}^{-}$, indicated that the formation of I-THMs was insignificant, that is, $0.1 \mu \mathrm{g} / \mathrm{L}$ under chlorination and $1.9 \mu \mathrm{g} / \mathrm{L}$ under chloramination.

The formation of HAcAms and their associated BSFs were positively related to the increase in $\mathrm{Br}^{-}$concentration under both chlorination and chloramination. Specifically, as the $\mathrm{Br}^{-}$ concentration increased from 3 to 33 and $68 \mathrm{mg} / \mathrm{L}$, the HAcAms increased from 11.6 to 14.4 and $20.6 \mu \mathrm{g} / \mathrm{L}$ under chlorination and from 0.4 to 0.5 and $1.3 \mu \mathrm{g} / \mathrm{L}$ under chloramination. Apparently, chlorination produced more HAcAms than chloramination. The dominant species of HAcAms were DHAcAms under chlorination, which agrees with the report from Chu et al. (2013); while

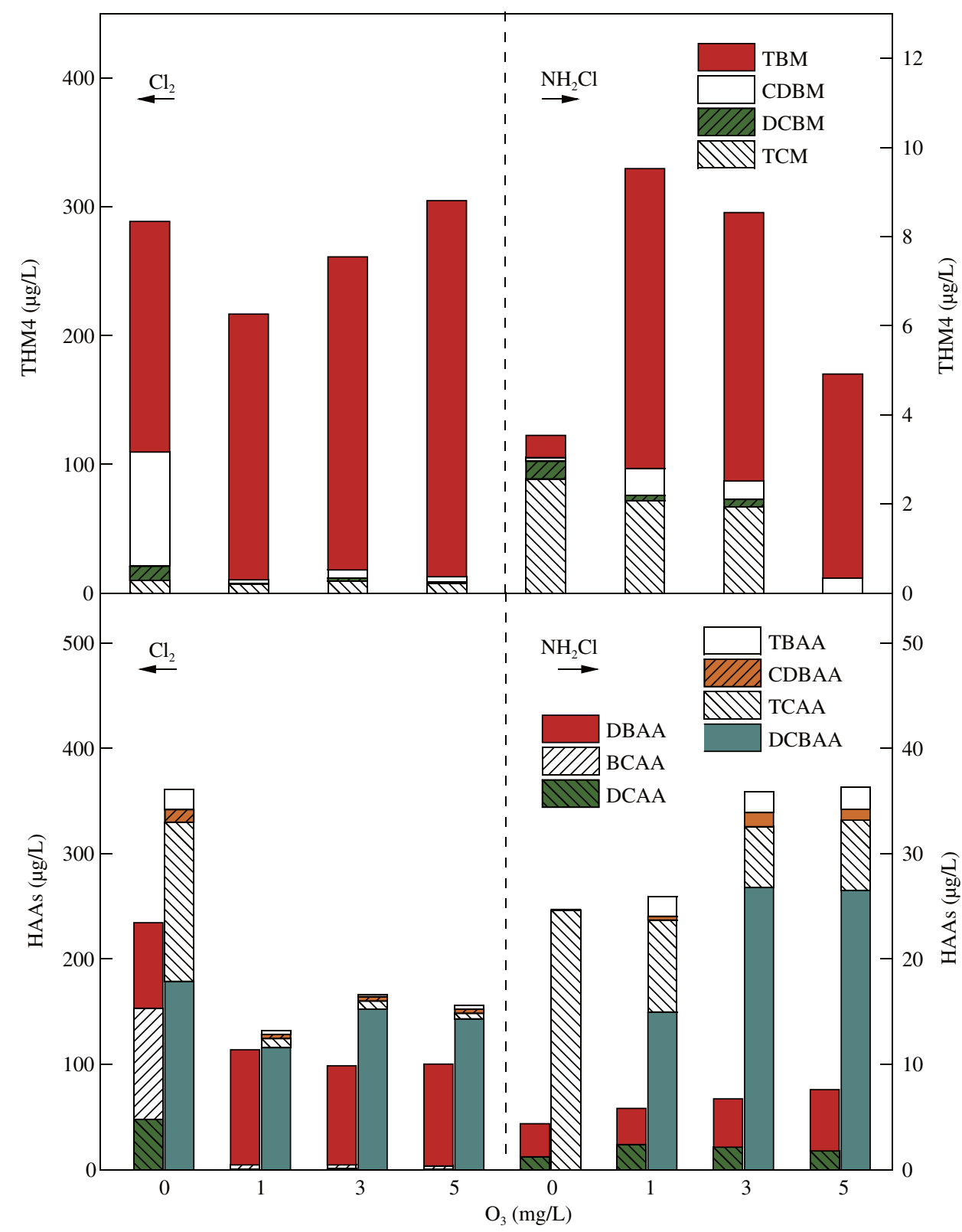

Fig. 4 - Effect of pre-ozonation on the formation of THM4 and HAAs (SLT seawater; $\mathrm{pH}=7.9-8.1 ; \mathrm{Br}^{-}$concentration = $3 \mathrm{mg} / \mathrm{L}$ ). The relative percent differences of all measurement data were below $18 \%(n=2)$. 
under chloramination, THAcAms predominated at high $\mathrm{Br}^{-}$ concentrations. The BSF values of HAcAms always increased with increasing $\mathrm{Br}^{-}$concentration in both disinfection scenarios.

\subsection{Effect of pre-ozonation on DBP formation}

\subsubsection{Formation of THM4 and HAAs}

$\mathrm{O}_{3}$ is often injected into the foam fractionation tanks in seawater treatment systems to remove suspended solids and decompose a certain portion of DOM. Ozonation can also alter the chemical properties of DOM, thereby influencing the formation of DBPs in the subsequent chlorination or chloramination (Tango and Gagnon, 2003; Hu et al., 2010). Fig. 4 shows that at low $\mathrm{O}_{3}$ dose $(1 \mathrm{mg} / \mathrm{L})$, the THM4 formation was reduced from 288.5 to $216.8 \mu \mathrm{g} / \mathrm{L}$ under the subsequent chlorination; thereafter a gradual increase in THM4 was observed as the ozone dose further increased to 3 and $5 \mathrm{mg} / \mathrm{L}$. Previous studies showed that ozonation with a low dose could break the aromatic rings and double bonds of DOM (Chang et al., 2002; Imai et al., 2009), thus reducing the THM4 formation to some extent. However, ozonation with a high dose may give rise to new organic precursors (e.g., methyl-ketone-like structures) from DOM to produce more THM4 during the subsequent disinfection process (Richardson et al., 1999; von Gunten, 2003). The formation of THM4 showed an opposite trend in the combined pre-ozonation and chloramination. The THM4 concentrations were always below $10 \mu \mathrm{g} / \mathrm{L}$, indicating that pre-ozonation had a limited impact on the THM4 formation under chloramination.

The effect of pre-ozonation on the control of DHAAs and THAAs under chlorination was obvious. Taking DHAAs for example, their concentration decreased remarkably from 334.4

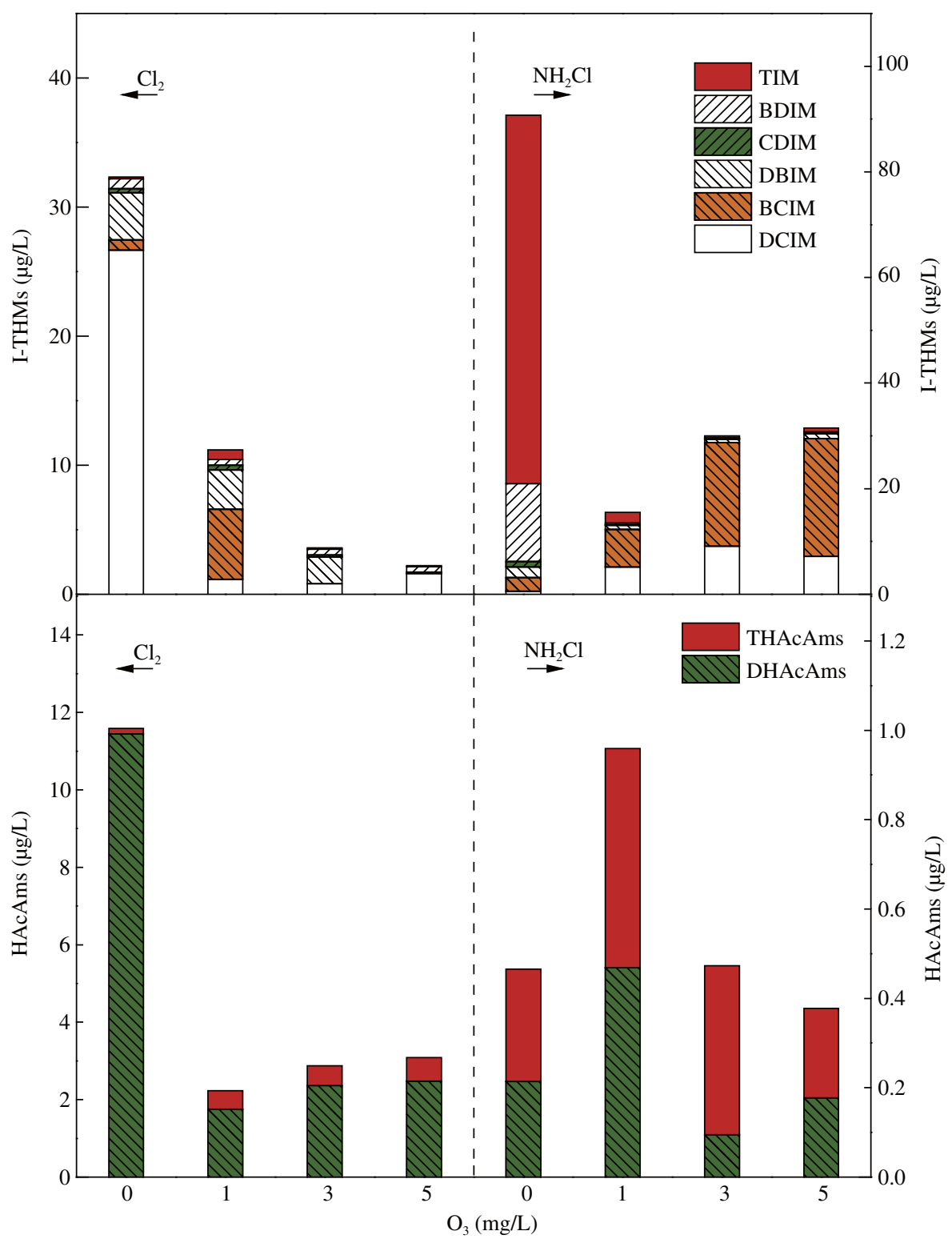

Fig. 5 - Effect of pre-ozonation on the formation of I-THMs and HAcAms (SLT seawater; $\mathrm{pH}=7.9-8.1 ; \mathrm{Br}^{-}$concentration $=3 \mathrm{mg} / \mathrm{L}$, spiked I- concentration $=500 \mu \mathrm{g} / \mathrm{L})$. The relative percent differences of all measurement data were below $15 \%(n=2)$. 
to $114.0 \mu \mathrm{g} / \mathrm{L}$ at $1 \mathrm{mg} / \mathrm{L} \mathrm{O}_{3}$ dose. However, further increasing the $\mathrm{O}_{3}$ dose to 3 and $5 \mathrm{mg} / \mathrm{L}$ could no longer reduce the formation of THAAs and DHAAs. By contrast, pre-ozonation promoted the formation of DHAAs and THAAs to some extent under chloramination, but all their concentrations were obviously lower than those formed under chlorination.

The chlorinated species, such as DCBM in THM4, DCAA in DHAAs, and TCAA in THAAs, decreased significantly with the addition of ozone, whereas the concentrations of TBM and DBAA increased. This is not surprising, as $\mathrm{Cl}^{-}$and $\mathrm{Br}^{-}$in seawater can be readily oxidized to $\mathrm{FC}$ and $\mathrm{FB}$ during ozonation, respectively (Qiang et al., 2012). The reaction rate constant of $\mathrm{O}_{3}$ with $\mathrm{Cl}^{-}$(i.e., $k_{1}=0.003 \mathrm{~L} /(\mathrm{mol} \cdot \mathrm{sec})$, Eq. (1)) is significantly smaller than that with $\mathrm{Br}^{-}$(i.e., $k_{2}=160 \mathrm{~L} /(\mathrm{mol} \cdot \mathrm{sec})$, Eq. (2)) (Haag and Hoigné, 1983a,b). In addition, $\mathrm{FC}$ can also react rapidly with $\mathrm{Br}^{-}$to produce FB ( $k_{3}=6.77 \times 10^{3} \mathrm{~L} /(\mathrm{mol} \cdot \mathrm{sec})$, Eq. (3)) (Bousher et al., 1986). Thus, the addition of ozone promoted the FB yield and ultimately increased the formation of Br-DBPs (Eqs. (4) and (5)) (Westerhoff et al., 2004).

$\mathrm{O}_{3}+\mathrm{Cl}^{-} \rightarrow \mathrm{OCl}^{-}+\mathrm{O}_{2} \quad \mathrm{k}_{1}=0.003 \mathrm{~L} /(\mathrm{mol} \cdot \mathrm{sec})$

$\mathrm{O}_{3}+\mathrm{Br}^{-} \rightarrow \mathrm{OBr}^{-}+\mathrm{O}_{2} \quad \mathrm{k}_{2}=160 \mathrm{~L} /(\mathrm{mol} \cdot \mathrm{sec})$

$\mathrm{HOCl}+\mathrm{Br}^{-} \rightarrow \mathrm{HOBr}+\mathrm{Cl}^{-} \quad \mathrm{k}_{3}=6.77 \times 10^{3} \mathrm{~L} /(\mathrm{mol} \cdot \mathrm{sec})$

$\mathrm{HOCl}+\mathrm{NOM} \rightarrow$ Products $\quad \mathrm{k}_{4}=0.7-5.0 \mathrm{~L} /(\mathrm{mol} \cdot \mathrm{sec})$

$\mathrm{HOBr}+\mathrm{NOM} \rightarrow$ Products $\quad k_{5}=15-167 \mathrm{~L} /(\mathrm{mol} \cdot \mathrm{sec})$

\subsubsection{Formation of I-THMs and HAcAms}

Fig. 5 shows that pre-ozonation obviously reduced the formation of I-THMs under both chlorination and chloramination. Under chlorination, the concentration of I-THMs significantly decreased from 32.3 to $11.2 \mu \mathrm{g} / \mathrm{L}$ at $1 \mathrm{mg} / \mathrm{L} \mathrm{O}_{3}$ dose, and then further to $2.2 \mu \mathrm{g} / \mathrm{L}$ at $5 \mathrm{mg} / \mathrm{L} \mathrm{O}_{3}$ dose; while under chloramination, their concentration remarkably decreased from 90.7 to $15.5 \mu \mathrm{g} / \mathrm{L}$ at $1 \mathrm{mg} / \mathrm{L} \mathrm{O}_{3}$ dose, and then gradually increased to $31.5 \mu \mathrm{g} / \mathrm{L}$ at $5 \mathrm{mg} / \mathrm{L} \mathrm{O}_{3}$ dose. I-THMs were produced from the reactions of HOI with DOM (Scheme 1). Ozone could oxidize a significant portion of $\mathrm{I}^{-}$to $\mathrm{IO}_{3}^{-}$through the intermediates $\mathrm{HOI}$ and $\mathrm{IO}_{2}^{-}$. Because $\mathrm{IO}_{3}^{-}$is unreactive toward DOM, the formation of I-THMs was significantly inhibited under both disinfection scenarios. FC could also oxidize $\mathrm{I}^{-}$to $\mathrm{IO}_{3}^{-}$as mentioned above, thus further strengthening the inhibition effect. However, $\mathrm{NH}_{2} \mathrm{Cl}$ could not oxidize $\mathrm{I}^{-}$to $\mathrm{IO}_{3}^{-}$, but only to HOI (Bichsel and von Gunten, 1999), which continued to react with NOM to produce iodinated DBPs. Results also indicate that with the increase in $\mathrm{O}_{3}$ dose, higher bromine substitution was observed for the formed I-THMs. For example, the dominant species shifted from TIM to BCIM under chloramination. This is because $\mathrm{O}_{3}$ could oxidize $\mathrm{Br}^{-}$in the seawater to $\mathrm{HOBr}$, which further reacted with DOM to produce brominated DBPs.

The concentration of HAcAms dropped markedly at $1 \mathrm{mg} / \mathrm{L}$ $\mathrm{O}_{3}$ dose, and then increased slightly with the continuous increase in $\mathrm{O}_{3}$ dose under chlorination, which is similar to the

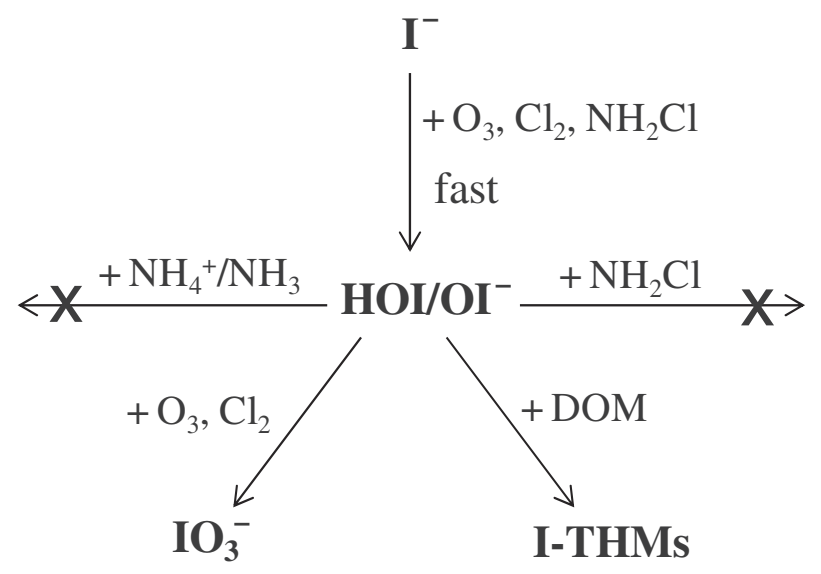

Scheme 1 - Reactions of $\mathrm{I}^{-}$with oxidants and dissolved
organic matter (DOM) in water.
Modified from Bichsel and von Gunten (1999).

formation of DHAAs and THAAs (Fig. 4). DHAcAms were always the dominant species of HAcAms regardless of the $\mathrm{O}_{3}$ dose applied. Under chloramination, the concentration of HAcAms exhibited an opposite variation trend, but always remained below $1 \mu \mathrm{g} / \mathrm{L}$. Both DHAcAms and THAcAms were the dominant species under chloramination.

\section{Conclusions}

This study investigated the formation of four classes of DBPs, including THM4, HAAs, I-THMs and HAcAms, in aquarium seawater under different water qualities and disinfection scenarios. After examining comprehensively the effects of the $\mathrm{DOC}$ and $\mathrm{Br}^{-}$concentrations in seawater and the $\mathrm{O}_{3}$ dose applied in pre-ozonation on the formation and speciation of studied DBPs, it can be concluded that chloramination produces much lower amounts of DBPs (except I-THMs) than chlorination, thus tends to be more suitable for seawater disinfection in marine aquaria with a low $\mathrm{I}^{-}$level (e.g., Beijing Aquarium without externally added $\mathrm{I}^{-}$ions). For marine aquaria using natural seawater or artificial seawater with externally added $\mathrm{I}^{-}$ions, pre-ozonation with a low $\mathrm{O}_{3}$ dose (e.g., $1 \mathrm{mg} / \mathrm{L}$ ) can effectively inhibit the formation of I-THMs.

\section{Acknowledgments}

This work was financially supported by the People Programme (Marie Curie Actions) of the European Union's Seventh Programme FP7/2007-2013 under a REA grant (No. 318926) and the National Natural Science Foundation of China (No. 51221892).

\section{R E F E R E N C E S}

Allard, S., Nottle, C.E., Chan, A., Joll, C., von Gunten, U., 2013. Ozonation of iodide-containing waters: selective oxidation of iodide to iodate with simultaneous minimization of bromate and I-THMs. Water Res. 47 (6), 1953-1960. 
Bichsel, Y., von Gunten, U., 1999. Oxidation of iodide and hypoiodous acid in the disinfection of natural waters. Environ. Sci. Technol. 33 (22), 4040-4045.

Bousher, A., Brimblecombe, P., Midgley, D., 1986. Rate of hypobromite formation in chlorinated seawater. Water Res. 20 (7), 865-870.

Chang, C.N., Ma, Y.S., Zing, F.F., 2002. Reducing the formation of disinfection by-products by pre-ozonation. Chemosphere 46 (1), 21-30.

Chu, W.H., Gao, N.Y., Yin, D.Q., Krasner, S.W., 2013. Formation and speciation of nine haloacetamides, an emerging class of nitrogenous DBPs, during chlorination or chloramination. J. Hazard. Mater. 260, 806-812.

Cowman, G.A., Singer, P.C., 1996. Effect of bromide ion on haloacetic acid speciation resulting from chlorination and chloramination of aquatic humic substances. Environ. Sci. Technol. 30 (1), 16-24.

Gonçalves, A.A., Gagnon, G.A., 2011. Ozone application in recirculating aquaculture system: an overview. Ozone Sci. Eng. 33 (5), 345-367.

Haag, W.R., Hoigné, J., 1983a. Ozonation of bromide-containing waters: kinetics of formation of hypobromous acid and bromate. Environ. Sci. Technol. 17 (5), 261-267.

Haag, W.R., Hoigné, J., 1983b. Ozonation of water containing chlorine or chloramines: reaction products and kinetics. Water Res. 17 (10), 1397-1402.

Hu, J., Song, H., Karanfil, T., 2010. Comparative analysis of halonitromethane and trihalomethane formation and speciation in drinking water: the effects of disinfectants, $\mathrm{pH}$, bromide, and nitrite. Environ. Sci. Technol. 44 (2), 794-799.

Hua, G.H., Reckhow, D.A., 2013. Effect of pre-ozonation on the formation and speciation of DBPs. Water Res. 47 (13), 4322-4330.

Hua, G.H., Reckhow, D.A., Kim, J., 2006. Effect of bromide and iodide ions on the formation and speciation of disinfection byproducts during chlorination. Environ. Sci. Technol. 40 (9), 3050-3056.

Imai, D., Dabwan, A.H.A., Kaneco, S., Katsumata, H., Suzuki, T., Kato, T., et al., 2009. Degradation of marine humic acids by ozone-initiated radical reactions. Chem. Eng. J. 148 (2-3), 336-341.

Jones, D.B., Saglam, A., Song, H., Karanfil, T., 2012. The impact of bromide/iodide concentration and ratio on iodinated trihalomethane formation and speciation. Water Res. 46 (1), 11-20.

Liang, L., Singer, P.C., 2003. Factors influencing the formation and relative distribution of haloacetic acids and trihalomethanes in drinking water. Environ. Sci. Technol. 37 (13), 2920-2928.

MarineBio, 2012. Worldwide aquariums and marine life centers. Available at:, http://marinebio.org/marine-aquariums/ (Date accessed: 12 October 2014).

Moren, M., Sloth, J.J., Hamre, K., 2008. Uptake of iodide from water in Atlantic halibut larvae (Hippoglossus hippoglossus L.). Aquaculture 285 (1-4), 174-178.

Obolensky, A., Singer, P.C., 2005. Halogen substitution patterns among disinfection byproducts in the information collection rule database. Environ. Sci. Technol. 39 (8), 2719-2730.

Plewa, M.J., Muellner, M.G., Richardson, S.D., Fasano, F., Buettner, K.M., Woo, Y.T., et al., 2008. Occurrence, synthesis, and mammalian cell cytotoxicity and genotoxicity of haloacetamides: an emerging class of nitrogenous drinking water disinfection byproducts. Environ. Sci. Technol. 42 (3), 955-961.

Qiang, Z.M., Adams, C.D., 2004. Determination of monochloramine formation rate constants with stopped-flow spectrophotometry. Environ. Sci. Technol. 38 (5), 1435-1444.

Qiang, Z.M., Jiang, Y.J., Ben, W.W., Adams, C., Dong, H.Y., 2012. Monitoring free chlorine and free bromine in aquarium seawater treated by ozone. Anal. Methods 4 (11), 3646-3652.

Qiang, Z.M., Zhang, H.T., Dong, H.Y., Adams, C., Luan, G., Wang, L., 2015. Formation of disinfection byproducts in a recirculation mariculture system: Emerging concerns. Environ. Sci.: Processes Impacts 17 (2), 471-477.

Richardson, S.D., Thruston, A.D., Caughran, T.V., Chen, P.H., Collette, T.W., Floyd, T.L., 1999. Identification of new ozone disinfection byproducts in drinking water. Environ. Sci. Technol. 33 (19), 3368-3377.

Richardson, S.D., Plewa, M.J., Wagner, E.D., Schoeny, R., DeMarini, D.M., 2007. Occurrence, genotoxicity, and carcinogenicity of regulated and emerging disinfection by-products in drinking water: a review and roadmap for research. Mutat. Res. 636 (1-3), 178-242.

Sharrer, M.J., Tal, Y., Ferrier, D., Hankins, J.A., Summerfelt, S.T., 2007. Membrane biological reactor treatment of a saline backwash flow from a recirculating aquaculture system. Aquac. Eng. 36 (2), 159-176.

Shi, H.L., Qiang, Z.M., Adams, C., 2013. Formation of haloacetic acids, halonitromethanes, bromate and iodate during chlorination and ozonation of seawater and saltwater of marine aquaria systems. Chemosphere 90 (10), 2485-2492.

Suzuki, Y., Maruyama, T., 2002. Removal of suspended solids by coagulation and foam separation using surface-active protein. Water Res. 36 (9), 2195-2204.

Tango, M.S., Gagnon, G.A., 2003. Impact of ozonation on water quality in marine recirculation systems. Aquac. Eng. 29 (3-4), 127-137.

von Gunten, U., 2003. Ozonation of drinking water: part II. Disinfection and by-product formation in presence of bromide, iodide or chlorine. Water Res. 37 (7), 1469-1487.

Wang, J.J., Chow, A.T., Sweeney, J.M., Mazet, J.A.K., 2014. Trihalomethanes in marine mammal aquaria: occurrences, sources, and health risks. Water Res. 59, 219-228.

Weinberg, H.S., Krasner, S.W., Richardson, S.D., Thruston Jr., A.D., 2002. The Occurrence of Disinfection By-products (DBPs) of Health Concern in Drinking Water: Results of A Nationwide DBP Occurrence Study. National Exposure Research Laboratory, Office of Research and Development, U.S. Environmental Protection Agency (EPA/600/R-02/068), Athens, GA, US.

Weishaar, J.L., Aiken, G.R., Bergamaschi, B.A., Fram, M.S., Fujii, R., Mopper, K., 2003. Evaluation of specific ultraviolet absorbance as an indicator of the chemical composition and reactivity of dissolved organic carbon. Environ. Sci. Technol. 37 (20), 4702-4708.

Westerhoff, P., Chao, P., Mash, H., 2004. Reactivity of natural organic matter with aqueous chlorine and bromine. Water Res. 38 (6), 1502-1513.

Wu, W.W., Chadik, P.A., 1998. Effect of bromide ion on haloacetic acid formation during chlorination of Biscayne Aquifer water. J. Environ. Eng. 124 (10), 932-938. 